Journal of the British Society for Phenomenology, Vol. 37, No. 2, May 2006

\title{
ONTOLOGY OF EVENTS VS. ONTOLOGY OF FACTS: ABOUT THE CURRENT FISSURES BETWEEN THE CONTINENTAL AND ANALYTIC TRADITIONS
}

\section{LUIS SÁEZ RUEDA}

\author{
Translated from the Spanish by Marcus Weigelt
}

We have, since the beginning of the 20th century, been witness to a conflict, occasionally explicit but for the most part tacit, between two philosophical traditions: the analytic and the continental. This claim might initially seem unprompted or exaggerated because it appears to presuppose the existence of two homogeneous totalities, which conflicts with the evident diversity of philosophical positions ascribed to each of the them.

This essay tries to show that we can indeed talk of two traditions and that between them there exists an ontological gap that endures in our days. It concerns what I shall here call the incommensurability between the continental ontology of events and the analytic ontology of facts. Both these ontologies have remained constant during 20th Century discourse in their respective circles, despite the profound differences between the philosophical positions within them. If this hypothesis were confirmed, we would be justified to talk of traditions in conflict, provided that we thereby refer not to two internally homogeneous unities but to two mosaics of theories that appear unified only when they are brought face to face with each other.

I shall try to give shape to this central thesis in three steps. I will start with a diagnosis of the continental ontology of events in connection with problems of the philosophy of mind. I will thereby regard as exemplary the conflict between a phenomenological conception on the one hand and the positions of Dennett and likewise Searle on the other (Part 1). I shall then try to demonstrate the way in which this ontology persists in continental philosophy through various transformations, in a process which I shall describe as "a locating of sense in the world" (Part 2). Finally, I will analyze the contrast of this ontology with the project of the naturalization of meaning in the analytic line of thought, a project that presupposes the ontology of facts mentioned above (Part 3).

1. The phenomenological ontology of acts: regarding Dennett and Searle in the philosophy of mind

Within phenomenology we may get a first idea of what I have called ontology of acts. When we confront it with Daniel Dennett's conception of the mind we can detect one of its central characteristics: it understands the real as a sense constituted from the life-world, the latter being a sphere of acts and not 
of rules. Another of its traits becomes apparent when we compare it with the position of John Searle: the fact that it affirms an a priori correlation between the constitution and the self-presentation of the real.

The issue raised by Dennett in the philosophy of mind has its origin in functionalism. Functionalism, as is well known, identifies the nature of a mental state with its function within a system of causal relations, that is, with its position and causal role in a functional organization by means of which information is processed. Its currently predominant version is that of computationalism, the basic idea of which is that a functional state is a computational state.

The original development of this programmatic theory was guided by the work of Turing. ${ }^{1}$ His proposals at the time meant an upheaval similar to the one that we witness today caused by the project of artificial intelligence (AI). We may distinguish, with a terminology expanded by Searle, between weak AI the point of view that the cerebral (and mental) processes can be simulated computationally - and strong AI - according to which having a program is all that having a mind consists of. ${ }^{2}$ Dennett's conception is consistent with this second line of thought.

Dennett gives the significant title of heterophenomenology to the basic orientation of his project. ${ }^{3}$ The heterophenomenological method begins by recognizing the existence of mental states that can be characterized in intentionalist terms in order to show, in a second step, that this existence is equivalent to the one that we attribute to illusions. With respect to what matters here, this method implies that mental phenomena are no longer described in a way in which we suppose that a phenomenologist would describe them. The latter would invoke experiences in the first person, in exactly the way in which they are understood from within, which provides information about what the intentional phenomenon is like for the subject, that is, what it is like within his introspective sphere. This is how the various inhabitants of the phenomenological garden are identified. In order to guard against prejudice, such a description should be neutral, and this, according to Dennett, forces us to adopt the third person perspective, that of an observer. In order to do so we adopt the tactics of leaving the subject which relates his phenomenological world and of transcribing his account as an interpreted text. Dennett calls this narrative fiction the heterophenomenological world: a world that constitutes a neutral and exact picture of what it is like to be that subject. The second step of this method consists in showing that the role of the agent presupposed as subject of this world can actually be played by a computational process. In such a case, consciousness and the whole intentional - phenomenological world are simply eliminated.

With regard to Husserl, this result would mean that the things floating in the stream of consciousness are not what we thought they were and that we have 
broken the spell of the phenomenological garden. ${ }^{4}$ Demystifying this phenomenological garden implies showing, against Husserl, the absence of phenomenology, for it takes the results of phenomenological introspection to be explainable from the third person perspective. ${ }^{5}$

What Dennett does is, from a certain point of view, to question Descartes' thesis that consciousness is an irreducible reality. ${ }^{6}$ His challenge is that what according to Descartes cannot be a dream, that is, self-consciousness, may itself be caused by a dream (an anonymous computation of connectionist nature). Dennett's error with respect to Descartes can be clarified if we consider the kind of experiences that the former associates with what he calls the inhabitants of the phenomenological garden. This list includes experiences of the external world (such as sounds and smells), experiences of the purely internal world (such as memories, images of fancy or sudden intuitions) and emotive experiences (such as tickle, pride, fear or remorse). ${ }^{7}$

When Dennett tries to show that this type of experience is produced within a complex mechanical organization, that is, that the first person perspective does not provide truth, he believes himself to be demolishing Descartes' edifice and with it phenomenology. What he is not taking into account is that Descartes would have no difficulties to agree with him. In the Meditations on First Philosophy the French thinker expresses himself absolutely convincingly in this respect. Persuaded that all contents of the mind might be a product of fiction, he supposes, in the second meditation, that he is dreaming. And he affirms that what is beyond all doubt, even during this mental experiment, is nothing that counts as contents of inner experiences, such as sensations, imaginings, perceptions or volitions. None of these, according to Descartes, amount to an irreducible experience, to a certain and straightforward reality. There is nothing in the content itself of the perception of some men walking in the street which would prevent us from supposing, he says, that they were hats and coats underneath which automata could be hidden. In this surprisingly to the computationalist - Descartes concedes to Dennett: whether or not that which the subject experiences possesses an intimate qualitative character is irrelevant with regard to the suspicion that it may constitute only an appearance for me, an appearance which might turn out fictitious. What, then, is the indubitable element? The indubitable element, that which by itself pertains to consciousness and is part of the irreducible $\mathrm{I}$, is the act of attending to these contents; it is neither the perception nor the experienced content, not even the perceiving insofar as it is a mental occurrence, but the act by which I attend to what I am perceiving or to what I seem to perceive. And what Descartes wants to say with this is that what properly belongs to the sphere of the subject is the dimension of self-apprehension in actu.

Everything that Dennett includes as component of the phenomenological garden has the form of a content that is experienced. In no way does he refer 
to the acts themselves by means of which one attends to these contents. And this, in virtue of the task itself of heterophenomenology, could not be any other way. If this method, as we have seen, proceeds from a third person description of the inner phenomenological world, then it is a method which excludes the actual dimensions of the acts as a matter of principle. If he had realized that the dimension of acts which Descartes refers to is, as a matter of principle, untranslatable into any form of objectively expressed information then it should have been clear to Dennett that this step already constitutes a corruption of that which has to be explained, namely the inner phenomenon. Hintikka has shown this with great mastery by taking the exemplary case of an act in the Cartesian world: the one expressed in the I think, therefore I exist. If this self-reflective act were translatable into an abstract logical objectification, then it could be considered a syllogism, a chain of reasoning composed of logical steps: a) All that thinks exists; b) I think; c) Therefore I exist. And this syllogism is either false or devoid of content. False, because in accordance with it Hamlet, who is made to think by Shakespeare, should have to exist. Empty because if, in order to save this situation, we would answer that we only refer to actual beings we would clearly be guilty of a petitio principi. This means that the truth of Descartes' argument is rooted in what is the result of a performative act, an act the content of which can only be apprehended in actu: the I think can never adopt the form it thinks. ${ }^{8}$ To my mind, these reflections lead to a destructive criticism of Dennett's very project (and along with it to that of any imaginable form of eliminative functionalism): it simply excludes a priori that which has to be explained and, in consequence, offers no explanation of consciousness.

It is precisely this dimension of an act that Husserl invokes in his transformation of Cartesianism. ${ }^{9}$ In phenomenological reflection, this Cartesian orientation is made good use of, but is also vigorously elaborated and deepened. The phenomenological method does not aspire to get access merely to the self-consciousness of the I think (which is actually empty), but to a whole field of transcendental experience which Husserl calls life-world (Lebenswelt). The phenomenological attitude lays open a new spectacle of the world which is articulated by two poles, one objective (the cogitatum or nóema), the other subjective (the thought of the object: cogitatio or nóesis). The appearance of the cogitatum as generated in the life-world coincides with the discovery of the real as a phenomenon of sense: a content that shows itself is reduced to the mode in which it shows itself (to the sense). Simultaneously, the world of the subject is rediscovered as a sphere of intentional acts of experience. It is indeed a sense that is experienced; on the basis of it we form an experience. What is important with respect to our problem is that this dimension of the act that constitutes the apprehension of a mode of presenting itself, of a sense, cannot be translated into an intellectual operation 
susceptible of empirical explication or description from the perspective of a spectator.

This is the key to the ontology of acts which I wanted to emphasize as underlying phenomenology. The following is a summary account of its central claim. The irreducible character of intentional consciousness is due to the fact that its Being has the dynamic form of acts, that is, there is one dimension of its nature that is not reducible to a static content of which we could give a distanced explanation or description. In the following I will provide more details to the sketch of this ontology, and I will show how its way of resisting Dennett's challenge differs from the one proposed by Searle.

In the words of Searle we may say that Dennett's project tries to show that there are no intrinsic mental phenomena, that is to say, that there are no phenomena that would have a first person ontology. ${ }^{10}$ Against this, Searle tries to show that the internal world of the subject has a qualitative character that is not reducible to formalization. With this line of argument he has for decades insisted on the difference between computation and comprehension. There is a mental experiment that the author tends to make use of, which is already commonplace in the analytic schools, and which people have been using as a model for justifying an anti-computationalist position: the so called mental experiment of the Chinese room. In this Gedankenexperiment Searle invites us to imagine that, in a situation analogous to that of a computer that receives inputs and emits outputs, we find ourselves in a room from which we communicate with the outside world in Chinese. In reality, we do not know Chinese, but we can simulate a conversation with a Chinese speaker situated outside and answering to questions by means of the use of a series of rules (given to us in our native language) which allow us to produce, and send outside the room, strings of Chinese symbols depending on the strings of symbols, likewise Chinese, which we receive through a connecting channel. Searle maintains that, given that we do not know Chinese, we do not comprehend the linguistic content by operating in this way and that such an activity of manipulating symbols cannot be considered an intentional activity, given that it is not an activity about that which the symbols represent. What this argument makes quite clear, according to Searle, is that computational operations, in so far as they are formal, are not in themselves sufficient as conditions of comprehension, and that the semantics is not intrinsic to the syntax.

We may stress two differences between the phenomenological approach and this Searlean argument. The first concerns the fact that Searle usually links the qualitative states that have reality in the first person with contents and not necessarily with acts. This is the case, for instance, when he refers to the sensation of pain. ${ }^{11}$ The advantage of the continental phenomenological position becomes visible here. The mere subjective existence of the qualia (the 
qualitative dimension of mental states) does not in principle represent any reason against the thesis that they are determined from below, from merely functional conditions. This, as we have seen, is justifiable from Descartes' point of view and, if the above considerations are true, does not constitute a serious obstacle against Dennett's suspicion. In order to withstand this suspicion it is necessary that we clarify not the content of the mental state but the act itself of its apprehension. And furthermore: not of the act understood as the occurrence of the mental state, for in that case there would be no difference with the trivial computational occurrence whereby, say, in a computer a window of Windows is opened. We are dealing with a performative act by means of which the mental occurrence (for instance a perception) is immediately accompanied by an attending to this occurrence. This other dimension, the properly Cartesian one, is that which, as we have seen, cannot be understood as derivative with respect to rules (Dennett), but only as a simple act (Hintikka).

The second difference concerns the relation between the world given in the first person perspective and the external or objective world. Phenomenology does not simply wish to affirm the existence of phenomena that, as Searle says, possess an ontology of the first person and whose existence would have to be recognized along with the realities described from the third person perspective. Searle takes good care to deny a necessary link between the two. After showing that the intentional mental states do not rest against a background of beliefs and capacities, he insists that it does not matter to the world how we represent or experience it, and that it is not relative to the above background. ${ }^{12}$ In view of this point we would have to say that the conception of the real as phenomenon of sense, already mentioned as a characteristic of phenomenology, implies that the reference made by consciousness is already a lived reference, one that is experienced as meaningful in the act of apprehension. And this means that there is nothing like a pure reference or an objective state of affairs to which a sense is further added. The reference itself is a mode of being comprehended. Here, the sense is the reference. The advantage that this phenomenological conception offers over the Searlean one when it comes to answering to Dennett lies in the fact that it enables us to unmask the very aim of heterophenomonology as lacking in sense. This aim is actually founded on an illusion: the illusion that there exists something like a pure and neutral perspective of an impartial spectator.

This unity of subject and world, of the experiencing and the experienced, is what Husserl qualified as the a priori correlation of nóesis and nóema. ${ }^{13}$ The meaning of this profound concept, which recurs throughout his work, helps to clarify the ontology of acts from another viewpoint. Not only the experiencing possesses a dynamic texture but also, as correlate of it, the experienced. To say that reality is a phenomenon of sense means that it is not reduced to a static 
experienced content. Not the real as phenomenon is present to consciousness, but the act itself of becoming present. This is why Husserl says that phenomenology is the description of that which is presented by itself. .4 And in understanding the real as presenting itself or as giving itself, the phenomenologist raises the dynamic dimension of this presenting of itself to experience to the rank of the ontologically primordial, and this we must not mistake for a static content that can be designated.

We can already guess why the ontology of acts is a particular case of the ontology of events. The acts of experiencing and being experienced take place, they occur. And we can also understand in which sense this ontology is opposed to what we call facts: the dynamis of the event is not something we can designate, it is not a fact or a factual reality. This latter ontology, however, is that which both Dennett and Searle, despite their difference, apply in their analysis of mental states.

\section{The Vicissitudes of the Continental Ontology of Events}

The above considerations allow us to make a general characterization of the conflict between the ontologies of events and of facts, which separate the continental and the analytic traditions. Before investigating its exact manifestations, I would like to specify synthetically the meaning given to these concepts. The ontology of events recognizes a dynamic and energetic dimension in the texture of the real which the term phenomenon contains in its Greek origin. It is the dimension of the showing itself or of the being constituted of a content which is distinct from the dimension, we could say horizontal rather than vertical, of the constituted or exhibited content. Such an ontology always features as part of the real an element that cannot be represented, that is to say, an element which cannot be translated as an objectivity capable of explanation or designation from the point of view of a third person, or distanced spectator. This ontology can be articulated in a language game, to speak metaphorically, in which we oppose signifying force to delineable sense, vertical intension to horizontal extension, dynamicity to staticity, energy to form. The ontology of facts, on the other hand, tends to comprehend the real as a space of entities that can be designated or reconstructed in law-like descriptions or explanations. The factual, however, is not in this case reduced to the empirical or demonstrable such as is common in a typically verificationist or positivist conception. It coincides, in its broadest sense, with that which is capable of being represented or described, that is, that which can be delineated or designated by an observer. If, in order to express the character of an event that cannot be represented, we have made use of contrasting terms, it would seem appropriate to use a typically analytical opposition in this second case. The most adequate may be the one that Wittgenstein uses in his Philosophical Investigations, ${ }^{15}$ when he refers to 
the difference between grammatical expressions and factual (or empirical) expressions. The former are those that in a determinate language game express immanent elements that specify a kind of use, practice or life form interwoven with this linguistic framework. Such elements can only be shown. They cannot be said, that is, they cannot be used in 'factual' propositions that delineate a space of reality in the world. This is due to the fact they are a condition of the meaningfulness of propositions of this second type, and are thus the hinges of the game on which the texture of the world depends.

In the following I will try to show, (1) that this ontological contrast separates Husserl from Frege, two figures who nonetheless coincide in an antinaturalist idealism, (2) that continental philosophy of the 20th century incorporates a reaction against the foundational idealist aspect in Husserl's thought, and follows a course of locating sense in the world, whereby the ontology of events is nonetheless preserved. In my final reflections I will maintain that the analytic tradition has followed a course that is structurally analogous to the previous. ${ }^{16}$ It incorporates a reaction against Fregean idealism, and it adopts the course of a naturalization of meaning which preserves the ontology of facts and to that extent preserves also the abovementioned conflict with the continental tradition.

\subsection{The conflict in the phase of anti-naturalist idealism: Husserl and Frege}

If we probe the philosophy of Frege in the light of the previous analysis, it is possible to find in it a phenomenological vocation. Frege distinguished two fundamental semiotic functions as a result of which expressions both have a reference and express a sense. ${ }^{17}$ Sense coincides, in the realm of nominal expressions, with the mode in which language presents us the object, such that sense is, according to Frege, a property of this mode of presentation. The sense of sentences is more complex and is expressed as ideas or thoughts. In both cases the referential reality is mediated by the intensional dimension of the sign function. The content of the understanding of the world - the continental philosopher would say - belongs to the medium of sense. And, what is especially interesting, this content seems to originate in a mode of presentation of the referent. All this invites us to suppose that the Fregean definition of the real belongs to the dimension of what in Husserlian terminology is denominated, as we have examined, its nóematic Being: its appearance as sense.

Together with this unity of vocation, the two authors have an anti-naturalist idealism in common. This is quite clear in the case of Husserl, for the phenomena of sense, or nóemata, are in his philosophy considered as ideal entities, and are never reducible to the contingency of time, culture or nature (and hence are not natural facts). Something analogous can be found in Frege's philosophy. ${ }^{18}$ Thoughts, for Frege, are ideal occurrences and, in contrast with 
psychological sensations, are not part of the causal nexus that constitutes the mechanism of the actual world. They are not part of that actual (wirkliche) world that is held together through the iron lines of causality.

There are, however, at least two big differences between Husserl and Frege in which the ontological gap to which I have been referring is manifest. The first has to do with the forms of their idealism. In accordance with the correlation that Husserl establishes between nóesis and nóema, sense is not only understood as an apprehendable ideality. That which shows itself by itself (the phenomenon of sense) is at the same time constituted in the subjectivity to which it presents itself. However, in Frege's theory there is no analogon of the aspect that correlates with this apprehension. We do not find in it a parallel analysis that would have transcendental acts as their object, in virtue of which thoughts are constituted as meaningful entities for the subject. The world of experience is for Frege a world of merely psychological acts, and hence he does not feel compelled to affirm the ontological productivity of life, its force of generating reality.

This difference leads us to a second element of contrast, and one that is fundamental. Here their distance from each other concerns the meaning of the concept of sense itself. According to the phenomenological point of view, the real as constituted in the life-world is a mode of appearance and is not reducible to a description or explication of that which appears as a compound of contents and attributes. But if one pays close attention, sense, for Frege, is primordially bound up not with this dynamic dimension, but with contents that can be logically described or reconstructed. Frege thought that the sense of a nominal expression could be objectified in a descriptive expression, and that the thought (or sense expressed in sentences) can be objectified in propositions and reconstructed by means of using a formal logic. It is enough in this context to remember that the Fregean horizon as proposed in his Conceptography is, as the subtitle itself summarizes, that of a "language of formulas, similar to that of arithmetic for expressing pure thought".

What turned out ontologically crucial for Husserl - the event itself of presenting something in its How (correlative to the life-world as the sphere of acts) - remains on the margin of what is emphasized by Frege's concept of sense, namely the semantic content insofar as it is an objectifiable static dimension. This contrast is a paradigmatic example of the difference that I have tried to establish between ontology of events and ontology of facts.

\subsection{The continental process of locating sense in the world}

Both the post-Husserlian continental philosophy and the post-Fregean analytic tradition actually coincide in one vocation: that of establishing independently of idealism - the processes of signification on the ground of the facticity of the world. Their distance from each other is nonetheless at the 
same time maintained, for in the case of continental philosophy its general direction is towards locating sense in the world in which the ontology of events is preserved, while in the case of analytic philosophy the direction is towards a naturalization of meaning in which the ontology of facts is firmly adhered to.

In this section I will restrict myself to giving a summary account of the continental positions, making reference to its principal currents of thought: Heidegger's fundamental ontology, post-idealist French phenomenology, hermeneutics, the Habermasio-Apelian new enlightenment and the thought of difference.

The first two above-mentioned lines of thought coincide chiefly in their deepening and twisting of the phenomenological conception of the real, while shifting the conditions of the constitution of sense from transcendental consciousness (Husserl) to a pre-reflective existence. In this way Heidegger does not abandon Husserl's key principle, but rather locates the phenomena of sense in the field of pre-conceptual experience, thereby transforming phenomenology into a hermeneutics of Dasein. ${ }^{19}$ It is clear that the ontology of events is preserved in this new terrain. For Being is conceived as the movement itself of "coming into presence" or "unveiling" $(\dot{\alpha} \lambda \hat{\eta} \vartheta \varepsilon \iota \alpha)$ that is never reducible to what is presented or occurs. ${ }^{20}$

An analogous transformation can be found in M. Merleau-Ponty, the main protagonist of that post-idealist French line of thought to which P. Ricœur has given the name of existential phenomenology, ${ }^{21}$ and whose influence comes back these days with a certain intensity. ${ }^{22}$ The pre-reflective terrain in which, in this case, the world is forged as an experience of sense, is that of the carnal subject, that of an intelligent corporality or savage being (être brut). The constitution of the real is on this ground understood also in dynamic categories: it concerns the "opening" of coordinates responsible for the possession of a world, ${ }^{23}$ of the spoken word (parole parlée) by means of which sense occurs and is made present through a state of arising ${ }^{24}$ or it concerns the interrogative questioning ${ }^{25}$ prior to any space of reflection. As B. Waldenfels claims with great mastery, the French philosopher was in all cases thinking of a vertical dimension of the generation of sense, one that is never reducible to the horizontal plane of descriptions or explanations of objects. ${ }^{26}$

If we now reflect on hermeneutics, we have no great difficulties in detecting another variant of the same ontology of events. In the perspective of Gadamer, Heidegger's principal disciple, the occurrence of Being is re-described as the upsurge and joining of different interpretations of the world, as the living dialogue of history. Events are now the movement of understanding itself and of understanding oneself within horizons of sense, a participatory process that can never be arrested by means of a methodological look, i.e., through representations distanced from occurring facts. ${ }^{27}$ In an analogous way, Ricœur has, since his earliest works, defended the irreducibility of interpretation, as an 
emerging event that is both rule-less and creative, with respect to the stratum of meanings sedimented in the explicit structure of language. ${ }^{28}$

We may at this point affirm that these three great lines of 20th Century continental philosophy locate sense in the world. The phenomenological conception develops a world-conception of sense to the extent that it is forced to radicalize the regress to the life-world advocated by Husserl. This is done by means of providing the supposed foundational character of subjectconsciousness with a different and deeper ground. The constitution of that which we call real is actually made dependent on a life-world, or Lebenswelt, with respect to which the reflective subject itself, the Cartesian subject, is no longer the origin but the product. The investigation of self-consciousness is replaced by a pre-reflective self-understanding and is made derivative with respect to it.

Nevertheless, this complex deepening of the regress to the life-world does not break up the correlation that Husserl established between the subject and the world, that complex and subtle relation that the father of phenomenology established between constitution (by the subject) and self-presentation (by the things themselves). This correlation, rather, is itself deepened and shifted. The bond between nóesis and nóema is now transformed to a connection between two mutually dependent events: on the one side the event of pre-reflective projection (as carried out by Dasein, the intelligent body or the interpreting agent); on the other side the event of coming into presence of the thing itself from an open horizon of sense.

The Habermasio-Apelian conception of reason already includes, in its very enlightenment terrain, a world-conception of $\log o s$, as the result of overcoming Kantian idealism by means of characterizing rationality as centred, that is, as inherent in the communicative praxis of the life-world. ${ }^{29}$ Situated in this realm of inner-worldly reason, the authors did not get rid of the nutritive soil of hermeneutics but have rather added to it. They both recognize that it is necessary to accept that the historical and corporeal opening of sense is a condition of what we call rational or true. Their critique consists in trying to show that together with this pre-logical dimension of events there evolves in history a process of justification of validity through argumentative discourse, and that between these two moments there holds a productive circle whose regulative idea is a counterfactual ideal speech situation (Habermas) or ideal community of communication (Apel). ${ }^{30}$ This amendment that preserves the ontology of events can further be perceived in all aspects of the new theory of enlightenment. In this way, for instance, finding out the presuppositions of reason (that is, of the universals of communicative rationality), is claimed by the authors to consist in the awareness in actu that we have "always already" (immer schon) recognized them. They thus possess a vertical reality in contrast to the horizontal nature of actual communication, to the point that 
Apel did not hesitate to clarify them, pitting Heidegger against Heidegger, as elements that belong to the "pre-structure" of being-in-the-world. ${ }^{31}$ It is already obvious that the rational element in the theories of Habermas and Apel is not a corpus of factualities (rules, facts, principles), but of presuppositions that possess the dynamic texture of a phenomenon. They certainly do not occur contingently, like in the three lines of thought analyzed above. If they are nonetheless a priori, this is due to the fact that they occur necessarily when rational activity gets underway.

In the case that was just analyzed, the continental ontology of events reveals a new face within a universalistic and enlightened code, inasmuch as the ontological conception of the real as sense is amended from within. In the French movement that has come to call itself the thought of difference (by authors like Deleuze, Lyotard or Derrida), we find an extremely radicalized version of this ontology, and one that leads to an internal subversion. If we take the especially influential example of Derrida, we can confirm that what Heidegger means by the "occurrence of Being" is put in question without abandoning a dynamic conception of what we call experience. According to this author, that which we call an experience of the world is something that adopts the form of difference. In an early work he clarifies this concept by taking recourse to the aporias between force (dynamis) and meaning (presence, form, structure). ${ }^{32}$ The static meaning paralyzes the dynamis, the force. Derrida then concludes that that which occurs in experience is a paradox, consisting in a dynamic emergence of a sense that collapses in this very same movement. This is not, as in Heidegger, an uncovering of sense but the impossibility of sense.

This summary account is sufficient to make us aware of the fact that Derrida stays attached to a conception of the real that preserves its characterization as event as the occurrence of difference. From another perspective, what Lyotard and Deleuze call difference is also a phenomenon that occurs. ${ }^{33}$ In the first, it occurs as a struggle between heterogeneous languages, ${ }^{34}$ while, in the second, it is manifest as the movement that arises from the encounter of two opposed forces or intensities..$^{35}$ In any case, in this French current of thought the ontology of sense is not abandoned in any strict sense either. For thinking difference implies, first of all, to situate oneself within a conception for which the real coincides in principle with the mode of presentation of experiences, with the signifying quality of its mode of being, and thus, secondly, the rupture or the internal aporia that constitutes this movement can be shown. If it be allowed to use a metaphor, it could be said that this locating of sense in the world becomes more extreme at this point insofar as it is turned more profane: the temple of sense is not being ignored but gets penetrated and its hidden and demonic face, its negativity, is unmasked. ${ }^{36}$ 


\section{The analytic naturalization of meaning and the conflict between the ontologies of events and of facts}

If we compare what has occurred in the analytic tradition of the $20^{\text {th }}$ century with the above continental movement, we will come across sufficient reasons in order to affirm a structural analogy. In Anglo-American circles, too, there is a predominant process of surrendering an idealist anti-naturalism, in this case that of Frege. For the philosophy of language has kept up a tendency towards a naturalization of meaning, that is, to link the processes of signification to conditions that are internal to the natural world. Fodor has described this process as a general ontological course according to which linguistic meaning is explainable along the same lines as, and as a continuation of, physico-natural reality. ${ }^{37}$ In accordance with the concept of an ontology of facts, as introduced above, this process contrasts with continental thought independently of the fact that the concept of the natural is associated with a physical description. The key to this contrast is contained in the fact that the natural is understood as the realm of objects or relations which can be represented and, at least in principle, reconstructed from law-like explanations or objectifiable descriptions. And it is also possible that this propensity is displayed within very distinct perspectives. I will point out three fundamental ones: one logical, another pragmatic and a third concerning the philosophy of mind.

From a logical viewpoint, Wittgenstein's Tractatus amounts to a fundamental step in this naturalization, because it reduces the intensional dimension of meaning to the extensional, to the reference, and the latter to the explainable or describable facts. Logical neopositivism took this as its point of departure, and it terminated in a scientific verificationism, thereby crossing paths with a phenomenalism that tends to reduce the constitution of objects to manifest psychological experiences. ${ }^{38}$

Wittgenstein basically identified the world with a logical form of language as a profound structure that only shows itself and that cannot be "said" by means of referential procedures. It could be thought that this position separates Wittgenstein from the ontology of facts, as opposed to what his vehement Viennese followers may have thought. And in fact, strong analogies may be drawn with Heidegger's thought, in the sense that the above profound essence of language and of the world, just like the phenomenon of Being, cannot be represented. ${ }^{39}$ Now, despite this structural similarity, an ontological gap is visible between them. For the logical form is not thought of as a dimension of events, but as a rigid and profound form of lawfulness. If it cannot actually be represented, it is at least conceived according to a standard of representation and indeed conceived as a static structure.

But the logical point of view was not abandoned in the decline of neopositivism. This is apparent, firstly, in a persisting tendency to a certain 
opposition with the continental ontology of events, rooted in the Tractatus: that of considering feasible the reproduction of the phenomena of natural language by means of formal languages. In a number of different positions this thesis is maintained during the sixties and seventies by Kripke, Putnam, Davidson, Montague, D. Lewis, B. Partee, N. Belnap jr., Stalnaker or D. Kaplan, a list to which in the eighties are added, among others, H. Kamp, Barwise, Perry and B. Richards. ${ }^{40}$

The logical project is rediscovered today, secondly, in an attempt that uses the concept of possible worlds in order to understand linguistic sense as a logical function. This programme, originally linked with the names Kripke and Putnam, has managed to constitute the basis for projects like those of Smith and McIntyre. These are projects that try to clarify phenomenological concepts, such as those of nóema and world of sense, through a logicomathematical formalization. ${ }^{41}$ And there is also a tendency to substitute the dynamical dimension of the constitution of sense for a lawful structure.

In the context of the pragmatic tradition we must at least be aware, first, of the line of thought that derives from Wittgenstein's turn, second, of the theory of speech acts and, last, of American neopragmatism - three strands that have contributed to such a naturalization by locating the processes of signification among the uses and habits of praxis. The first of them has explicitly served as battleground for the conflict between the great traditions. In his Philosophische Untersuchungen, Wittgenstein had associated meaning with use and the internal forms of life with concrete language games. The analogy with Heidegger is again apparent. For one could interpret the concept of a language game as being in tune with that of the world of sense, if one considers that to participate in a linguistic praxis implies belonging to an understanding of the world that cannot be represented. But this does not seem the predominant reception in the analytic tradition. And so Kripke's communitarian interpretation came to be very influential; it explained the practices in the games in terms of a behaviourist naturalism, as the describable modes of behaviour of a community. ${ }^{42}$ And a naturalist project can also be attributed to the holistic views held by authors such as Quine and Davidson. ${ }^{43}$

The theory of speech acts, as developed by Austin and Searle, also lends itself to an analogy with the continental tradition. As indicated by Derrida, this conception suggests a recognition of the dynamic dimension of speech that cannot be represented, and it does so by making the meaning of propositions depend on the performative aspect of the acts in which they occur: the performative aspect is thought of as a force..$^{44}$ But again it seems that if we take a closer look we can recognize here a case of the ontology of facts. For, as Searle has indicated, the speech acts evolve within a framework of a behaviour governed by rules, rules that belong to conventions and that are institutional facts. ${ }^{45}$ 
Finally, American pragmatism (like that of Dewey) links the meaning of expressions to practical foreseeable operations. Operationalism in physics, behaviourism in psychology or sociologism in the theory of knowledge are expressions of this line of thought. The institutional facts that Searle refers to, as much as the pragmata that the American pragmatism thinks of, are quite obviously governed realties and can be represented by descriptions or explanations. They are factualities, though nonetheless very different from that vertical and dynamic reality that Merleau-Ponty, for instance, recognizes as being at the basis of all corporeal operation or of all behaviour, and which he defines as a creation of rules that itself is not, and cannot be, governed by rules.

As I have indicated, the movement that seems currently predominant in the philosophy of mind is one of computational functionalism. But even in nonreductionist positions opposed to it we can rediscover, though on a different level, the ontology of facts. I will consider two examples.

The first example makes reference to Davidson. The anomalous monism that he defends tries to make the irreducibility of the intentional compatible with a materialist characterization of the mind. ${ }^{46}$ The argument goes as follows: the content of a mental state cannot be determined other than in relation to a complex holistic network of states that constitute the global context. Now, if this is the case, then the mental states, though they may be identical with physical states when taken in isolation, cannot be taken as correlatives of the determined physical causal chain. Any connection between a mental and a physical property would only have an accidental character, and would always be insufficient for establishing lawful predictions. This position, then, does not escape the ontology of facts either. In reality, the irreducibility of the mental-intentional aspect is not made by Davidson to depend on its ontological character, but on the fact that the epistemological access turns out insufficient or limited in order to get to a material reality. But for the continental philosopher, the irreducible character of an non-naturalizable dimension has an entirely ontological sense.

The last example refers to authors who return explicitly to positions of continental origin, such as that of Heidegger and Merleau-Ponty, in order to confront them with computational functionalism. Among them are H.L. Dreyfus, A. Clark, R.A. Brooks, J. Mc Dowell and M. Wheeler. If this recourse is made rigorously, then, naturally, we will not find a reason for controversy. The problem arises from a suspicion as to whether they do indeed do justice to the ontology of events that is implicit in its sources. Without wishing to generalize, it is quite possible that in the translation of the continental source into the analytic context the former may have been purged of its ontology and forced into a re-elaboration based on the ontology of facts. This impression is produced by at least some of their contributions to the idea of an artificial life. ${ }^{47}$ 
A common idea in these contributions is that human activity is a combination of abilities and practices that are not intentional states and which hence do not possess a representational content, which is why they cannot be explained in terms of elements and rules. If this impression were correct, then our objections would be similar to the ones brought to bear against Searle. In order to do justice to the continental position it is not enough to admit the existence of a pre-representational world, but to rediscover the intentional dimension in the profound origin of such a world. Otherwise its constitutive elements are reduced to contents of another kind. And this is not, as was shown above, what the continental philosopher thinks of, because what he does think of is rather the force of generation or opening-up which is presupposed in the presentation of whatever content.

We not only detect a profound difference between the two traditions. We also detect a risk that this difference should end up in a mutual indifference. This would be something quite unusual in the history of philosophy. For until now, the opposed positions have, in one way or another, constantly entered into controversy. But those of us who dedicate themselves to philosophy today are confronted with a situation in which both traditions are closing themselves off from each other. It is not the conflict but the possibility that the strength for a proper conflict is lost that constitutes the actual risk. To know what it is that separates the one tradition from the other is a necessary condition for engaging in this real and rewarding conflict.

Universidad de Granada

\section{References}

1. Turing, A. M., "Computing Machinery and Intelligence", Mind, 59 (1950), pp. 433-460.

2. Searle, J., The Rediscovery of the Mind, The MIT Press, Cambridge, Massachusetts, 1992, chapter $9, \S 2$.

3. In what follows I am mostly referring to chapter 4 of Dennett, D., Consciousness Explained, Little, Brown and Company, Boston, 1991.

4. See Dennett, Ibid., chapter $3, \S \S 3$ and 4.

5. See Dennett, "On the Absence of Phenomenology", in D. Gustafson and B. Tapscott (eds.), Body, Mind and Method, Dordrecht, Reidel, 1979.

6. Dennett in this matter frequently refers to Descartes. See, for instance, his Consciousness Explained, op. cit., chapter $1, \S 2$ y chapter $2, \S 3$.

7. See Ibid., chapter $3, \S \S 1$ and 2 .

8. See Hintikka, J., "Cogito, ergo sum: Inference or Performance?", in W. Donney (ed.), Descartes. A Collection of Critical Essays, New York, 1967, pp. 108-139. Also Hintikka, "A Discourse on Descartes'Method", in M. Hooker (ed.), Descartes. Critical and Interpretative Essays, The John Hopkins, University Press, Baltimore-London, 1978, pp. 74-88.

9. For what follows, see Husserl, E., Cartesianische Meditationen (Ha., I), especially $\$ \S 1,2$, 8, 9 and 14. About this, the excellent clarification given by Landgrebe, L., Der Weg der Phänomenologie, Gütersloh, 1963, and Waldenfels, B., In den Netzen der Lebenswelt, Frankfurt, Suhrkamp, 1985, chapter I.

10. For what follows, see Searle, The Mystery of the Mind, New York Review of Books, 1997, chapter 5 . 
11. This is the example with which Searle begins chapter five of his already referred to The Mystery of the Mind.

12. See Searle, J., The Rediscovery of the Mind, The MIT Press, Cambridge, Massachusetts, 1992, chapter. 8, section IV.

13. Ideen, I, § 86 .

14. Ideen, I, $\S \S 23$ and 24.

15. For instance, $\$ \S 251,295,458$.

16. This problems are discussed in more detail in Sáez Rueda, L., El conflicto entre continentales y analíticos, Barcelona, Crítica, 2002.

17. Paradigmatic in this line is the famous essay of 1892, Frege, G., "Über Sinn und Bedeutung", in Kleine Schriften, Georg Olms Verlag, 1967.

18. See, for instance, Frege, G., "Der Gedanke. Eine logische Untersuchung", in Beiträge zur Philosophie des deutschen Idealismus, 1, 1918-19, pp. 58-77.

19. Heidegger explicitly expresses this in Sein und Zeit, Tübingen, Max Niemeyer Verlag, 1986, $\S \S 5-7$.

20. See Ibid., § 44 .

21. Ricoeur, P., "Phénoménologie existentielle", Encyclopédie française, XIX (1957)..

22. In authors like M. Haar, M. Henry, M. Richir, H. Maldiney or, in Spain, D. Blanco Fernández, among others.

23. See Merleau-Ponty, M., Phénoménologie de la perception, Paris, Gallimard, 1945, chapters III and IV.

24. See Ibid., chapter. VI.

25. See the chapter entitled "Interrogation et Intuition", en Merleau-Ponty, M., Le visible et l'invisible, París, 1964.

26. Waldenfels, B., In den Netzen der Lebenswelt, Frankfurt a. M., Suhrkamp, 1985, chapters 3 and 4, and also Deutsch-Französische Gedankengänge, Frankfurt a. M., Suhrkamp, 1995, chapters 7-10.

27. This precisely is the central idea of Wahrheit und Methode, Tübingen, Mohr, 1951. See, for instance, the introduction and $\S 9$.

28. See, for instance, "La structure, le mot, l'événement", in Ricoeur, P., Le conflit des interprétations, Paris, Éditions du Seuil, 1969.

29. See Habermas, Nachmetaphysisches Denken, Frankfurt a. M., Suhrkamp, 1988, chapter I, § 3.

30. See Habermas \& Apel, K.-O., "Sinnkonstitution und Geltungsrechtfertigung", in Forum für Philosophie Bad Homburg, ed., Martin Heidegger: Innen- und Außenansichten, Frankfurt a. M., Suhrkamp, 1989, pp. 131-175.

31. Apel, K.-O, Diskurs und Verantwortung, Frankfurt a. M., Suhrkamp, 1988, pp. 40-50.

32. See Derrida, J., "Force et signification", chapter. 1 of L'écriture et la différence, Paris, Gallimard, 1967.

33. See Sáez Rueda, L., "Das Unverfügbare und der Diskurs 'Heideggers Vermächtnis im Streit von Moderne und Postmoderne", Wiener Jahrbuch für Philosophie, XXX/1998 pp. 191214.

34. See Lyotard, J.-F., La condition postmoderne, Paris, Minuit, 1979, chapters 3 and 14; Le Différend, Paris, Minuit, 1983, for instance, $\$ \S 3,21-23$ or 35-45.

35. The analysis of these "differential systems" is the central topic of Deleuze, G., Logique du sens, Paris, Minuit, 1969.

36. See Sáez Rueda, L., Movimientos filosóficos actuales, Madrid, Trotta, 2001, chapters 15 and 16.1 .

37. Fodor, J., The Elm and the Expert, Cambridge, MA: The M.I.T. Press, 1993, p. 5.

38. This was aimed at around the beginnings of the century by B. Russell y R. Carnap. V. Carnap, R., The Logical Structure of the World, California, 1928, for instance $\S \S 3,64$.

39. See Apel, K.-O., "Wittgenstein und Heidegger: kritische Wiederholung und Ergänzung eines Vergleichs", in McGuinness, et. al., Der Löwe spricht ... und wir können ihn nicht verstehen, Frankfurt a.M., Suhrkamp, 1989, pp. 27-69. 
40. See Acero Fernández, J.J., "Después del análisis: significado, comprensión e intencionalidad", in Torrevejano, M., Filosofía analítica hoy. Encuentro entre tradiciones, Univ. Santiago de Compostela, 1991, pp. 9-25.

41. Cfr. Smith, D. W. y McIntyre, R., Husserl and Intentionality, Dordrecht, D. Reidel, 1982, chapters V and VI.

42. Kripke, S., "Wittgenstein on Rules and Private Language", in Block, I. (ed.), Perspectives on the Philosophy of Wittgenstein, Oxford, Blackwell, 1981, pp. 238-312.

43. Such as R. Rorty maintains in "Wittgenstein, Heidegger und die Hypostasierung der Sprache", en McGuinness, et. al., Der Löwe spricht ... und wir können ihn nicht verstehen, op. cit., pp. 69-94.

44. See Derrida, J., "Signature, évenement, contexte", in Marges. De la philosophie, Paris, Minuit, 1972.

45. Searle, J., Speech Acts, London, Cambridge Un. Press, 1969, chapters 2.5 and 2.7.

46. Especially significant are the works included in Davidson, D., Essays on Actions and Events, Oxford, Clarendon Press, 1982.

47. Cfr. Boden, M. A. (ed.), The Philosophy of Artificial Life, Oxford, Oxford Univ. Press, 1996. 